\title{
Eldorado Revisited: Spanish Film-makers in Reagan's America
}

Vicente J. Benet

\section{(2) OpenEdition \\ Journals}

Electronic version

URL: https://journals.openedition.org/ejas/8787

DOI: $10.4000 /$ ejas.8787

ISSN: 1991-9336

Publisher

European Association for American Studies

\section{Electronic reference}

Vicente J. Benet, "Eldorado Revisited: Spanish Film-makers in Reagan's America", European journal of American studies [Online], 5-4 | 2010, document 7, Online since 15 November 2010, connection on 08 July 2021. URL: http://journals.openedition.org/ejas/8787 ; DOI: https://doi.org/10.4000/ejas.8787

This text was automatically generated on 8 July 2021 .

Creative Commons License 


\title{
Eldorado Revisited: Spanish Film- makers in Reagan's America
}

\author{
Vicente J. Benet
}

1 In the early 80s, two well-known Spanish directors made independent films during their short stays in the United States. On the Line (Río Abajo, José Luis Borau, 1984) and Reborn (Renacer, Bigas Luna, 1981) focused on American society at the beginning of the Reagan era. ${ }^{1}$ Both offer a cinematographical document on how the ideas, icons and symbols of that time were seen through foreign eyes. Borau and Bigas Luna's ambivalence toward American society translates into their films as a feeling of estrangement that is as fascinating as it is disconcerting. ${ }^{2}$ And both films pan out the dark side of the American dream: while On the Line examines the cruel, illegal trafficking of Mexican immigrants, Reborn uses sharp irony to portray religious preachers. The substantial narrative material in these films is channelled through specific formal techniques and in this study I aim to highlight how the two films work in strikingly similar ways.

2 On the Line and Reborn actually predate themes that are being taken up in current cultural and social research on trans-nationality, exile and diaspora, that is, conflicts coming out of cultural clashes and differing traditions from social groups that share the same space. ${ }^{3}$ Along these lines, many modern film scholars examine how political, economic, cultural, or sociological conditions generate the values and symbols which go into forming social identity. The crux of the theoretical debate on different degrees of culturalidentity, especially in the last twenty years in Europe, has grown out of an ever-increasing number of directors, writers and artists who have emigrated to America, or even more so of second-generation immigrants who reflect a strong connection to both cultures in their work.

3 One particularly illuminating aspect is that, in the two films, questions of social conflict form part of the narrative structure in similar ways. The aim was to reflect a moment of fundamental transformation in American society. After the liberalism of the 60s, the lost Vietnam War, and with the continual threat of the Cold War, there was a trend to return to what were considered traditional American values, culminating in the 
election of Ronald Reagan as president in 1980 . This shift in values was backed by the mass media which were themselves undergoing a technological revolution of their own at the time with, for example, satellite communication and the widespread use of video. Martin Amis describes the cultural changes going on in his biting journalism, his articles published under the telling title The Moronic Inferno. ${ }^{4}$ There was a strong current on the part of conservative thinkers such as Leo Strauss or Alasdair MacIntyre giving fuel to this return to traditional values. MacIntyre, for example, called for virtue in the face of a corrupted society, while he also defended the idea of the coming of a new Saint Benedict. ${ }^{5}$ In sum, this was the kind of writing that contributed to the ideological and political profile of the conservative revolution, whose influence is still felt in many sectors of American society today. ${ }^{6}$

4 We find that both films represent the conflict between a unified sense of American identity based on conservative values which is threatened by the appearance of other external forces, such as Mexican workers or authentic religion not invested in superficial spectacles that call it into question. The films bring this out through a schematic and apparently Manichean structure. On the one hand, the characters that come from the foreign culture are female: Engracia, a Mexican prostitute in On the Line (played by the Spanish star Victoria Abril) and Maria, an Italian woman who has genuine spiritual experiences and stigmata (Antonella Murgia) in Reborn. This brings in a political dimension dealing with gender issues as well. As antagonists, we have two violent, machista male characters who portray paternal, repressive figures. In their iconographic construction, they represent a nearly archetypical caricature of America -the cowboy hat, the boots, the pistol, etc.-phallic symbols for a grotesque rendition of the illegal immigrant hunter Mitch (Scott Wilson) and Giacomo (played by the Spanish actor Francisco Rabal), the thug who works for the managers of the religious show. The antagonists will then clash with younger American male characters, which brings in an oedipal dimension to the story. These young, unprejudiced men represent an America in transformation by rebelling against the paternal characters and pairing up with the foreign women. The films take the progressive stance that it is possible for different cultures to co-exist. However, the endings are tainted with a good dose of scepticism, given the dominance of the conservative ideology that grew during the early years of Reaganism.

5 In fact, these films leave the question open, pointing to a future in which no real solution to the clash of cultures is in the offing. This ambiguity is substantiated in both films through what I would say are the most interesting characters, who bring more depth to the question of American identity. They are complex characters, defined precisely by their inherent contradictions. Even though they still cheat and exploit others, they are disillusioned with their old system of values and become the site where a change could possibly occur. Our Spanish directors chose two veteran American actors for these roles: Dennis Hopper (as Reverend Tom Hartley in Reborn) and David Carradine (Bryant "The Coyote" in On the Line). It may be relevant to take into consideration what these actors represent off-screen. Hopper and Carradine were famous stars, but they did not come out of the grand Hollywood studios. They got their start in television, independent B series, or cult films which eventually became international hits. Their public image was not that of the typical Hollywood star, and they were occasionally linked to prestigious European directors, something which gave them a certain aura of sophistication and difference. ${ }^{7}$ Production was difficult and the films were financed mainly by Spanish capital-in Borau's case he financed the movie 
himself. ${ }^{8}$ They did not go on to become huge hits. In fact, their success at the box-office was quite limited. They received little distribution in the United States, although they did make quite an impact in Spain, especially among the critics. The fact that they did not clearly relate to a specific nationality in terms of production caused problems at film festivals since they could not be classified as either American or Spanish. ${ }^{9}$

6 In order to clarify questions of style and narrative construction, it helps to look at what was happening with the two Spanish directors preceding their arrival to the United States. In the early 1970s, both had received critical acclaim and had a substantial public following. Up to that time, José Luis Borau had supported himself teaching at the Official School of Cinematography in Madrid while working on film projects such as television programs, and even making spaghetti-westerns. He was finally recognized as a true film auteur with Furtivos (1975) which was immediately cited as one of the best films made at the beginning of Spain's new democracy. It dealt with violent power relationships as reflected through the story of an incestuous family, effectively capturing unspoken feelings of trauma in Spanish society. Bigas Luna, on the other hand, quickly rose to popularity because of his provocative and original film style. While he, too, delved into lurid details, his themes were directed more toward fetishist sexual obsessions of control and domination as in his films Bilbao (1978) and Caniche (1979).

7 Even though Borau and Bigas Luna vary greatly in terms of style and theme, what brought them both acclaim in Spain was the manner in which they broke out of the style referred to as the "aesthetics of repression," typical of the last years of the Franco dictatorship and the beginning of democracy. ${ }^{10}$ Representative of that style are the early 1970s films of Carlos Saura and Elias Querejeta, which were internationally known through film festivals and specialized journals. The "aesthetics of repression" was mainly based on personal or family stories which metaphorically stood for political conflicts. The Franco dictatorship was typically depicted through a tyrannical, controlling character (paternal figures, for the most part), and younger, obsessive characters who challenged them. These were fairly complex and structurally sophisticated films, and were meant to be a form of resistance. However, they had little impact outside the small, elite circles of film buffs, film festivals, or among those who frequented the art theaters, although there were a few exceptions to the rule as with the case of Cria Cuervos (Saura. 1976).

8 Borau and Bigas Luna took different routes in challenging the aesthetic norms. In Furtivos, Borau dealt with themes that scholars have described through a variety of metaphors, all of which ultimately refer to a regressive and child-centered ${ }^{11}$ representation of violence and sexual trauma within a perverse family setting: incest, cainism, ${ }^{12}$ blood cinema, ${ }^{13}$ or indecent exposure. ${ }^{14}$ However, his style was neither heavily rhetorical nor covert. On the contrary, he had a straightforward, naturalistic style in which violence was direct and forceful. ${ }^{15}$ Bigas Luna, on the other hand, left behind entirely any trace of the old aesthetics. He was also interested in the possibilities of constructing metaphors through film, but he had utterly different intentions to previous film-makers. In Bilbao, his treatment of a character's obsession with a prostitute was relatively original, and on many occasions the mise-en-scène was heavily strewn with symbolic references. Such references were not meant to encourage a political reading, however, but were sophisticated allusions to pop culture, advertising, or design. 
9 Both films use patterns from existing film genres, but also bring in significant innovations. On the Line is a border movie. The initial action scene clues us into the narrative and the symbolic sense of the movie. A group of "wetbacks" is trying to cross the Rio Grande with their guide el Coyote (David Carradine). We later find out that Coyote is an ex-border patrol agent who has gone bad and ended up working for "el Gabacho" (Sam Jaffe), the old man who runs the illegal business. ${ }^{16}$ The main conflict is produced in the river, which is used as a strong metaphor in the film. The river is where Coyote has his first run-in with Mitch, the ruthless agent who patrols the area in his small aircraft, terrorizing anyone trying to cross it. Mitch's voice is heard booming from a speaker on his aircraft, spewing constant threats at the immigrants. From the very start of the film, the river is deployed as a traditional trope referring to life and death. The sense of death comes out at the start of the film, with the immigrants who drown because of Mitch's harassment. The story will come round full circle when, at the end, Mitch's own dead body will float down the river. More than a geographical border, the river stands for death and disappearance. There are a couple of times in the movie when a character will see an object floating down the river and say "what goes downstream belongs to nobody" which reflects not only the notion of futility and loss, but also of a-temporality and circularity, elements long part of the rhetorical and literary images of rivers.

10 To solidify his symbolic construction of the river, Borau uses the narrative strategy of a character maturing into adulthood.Two young men, Chuck (Jeff Delger) and Jonathan (Paul Richardson), arrive in Laredo searching for adventure. They want to become border patrol agents like Chuck's uncle (el Coyote) whom they idolize. They are both extremely naive, and this is brought out in the near-ridiculous experiences they have with Mitch and across the border with el Coyote and Engracia, a prostitute at the Papillon bordello in Boystown, where gambling and prostitution are common. It initially looks like this is going to be the story of Chuck's coming of age, his initiation to sex and his awakening to the social conflicts at the border. But the narrative point of view is actually rather more complicated than this. In fact, the story-line veers away from Chuck to focus on Engracia-a more mature and interesting character. The shift in narrative focus brings into play a question of greater ethical dimensions. Borau's goal is to show the audience the process of Engracia overcoming her sexual and economic exploitation and becoming a new person struggling to adapt to a new country. Note that the first encounter of all the main characters happens in the symbolic space of the zone. The zone is in Mexican territory, but it is a hybrid space, where characters like Mitch can go for women, booze and gambling. The visual symbolism strikingly contrasts the brilliant colors in Mexico with the monochromatic, desert tones of the American side of the border. ${ }^{17}$ In sum, the border (the river and the zone) is the place where we find the basic passions of life and the unstoppable presence of death.

11 Mitch helps Chuck find his uncle, el Coyote, who is in the Papillon bordello, where he is recovering from injuries he suffered in a failed immigrant crossing. Out of gratitude, he lets Chuck spend some time with Engracia. Chuck is immediately taken with the young prostitute, thus bringing the romance into the narrative line. It also brings out the conflict with Mitch, who uses Engracia to show Chuck that he rules the situation. It is not that he dominates just Engracia, as a woman and as a Mexican. He also dominates Chuck who, with his doubts and his lack of racial prejudices, constitutes a challenge to the sense of a unified, monolithic American culture represented by Mitch. ${ }^{18}$ 
12 Engracia's identity is fully brought out about one-third of the way into the movie and the possibility of her integration into American culture is the primary thrust of the narrative from this point on. There is a key scene in which Chuck and Engracia are about to cross the border into the US after getting married in Mexico. At the border control, the agents question whether the marriage is legal or not and Chuck has to go into the office to clear up the problem. While Engracia waits for Chuck, she sees a group of Mexicans being deported back to their country. This is a key moment when Engracia crosses the border psychologically, so to speak, and suffers a crisis of identity that will push her to abandon Chuck and join the group of deported immigrants. ${ }^{19}$ This is the only moment in the film, apart from a loose comment by El Gabacho, when the social problem of immigration is integrated into the motivations of the main characters. At this point, Engracia's interiorizes the social question of her identity and this is the key to understanding the motivation for her actions in the rest of the film. In fact, the clash between a monolithic and intolerant American identity represented by Mitch and the more open-minded Chuck is not resolved as a conflict between the two men, as would have been conventionally done. Chuck ends up in jail for trying to bring Engracia illegally across the border and is consequently entirely out of the picture. The conflict is actually resolved by Engracia, who is endowed with a new identity, fighting to assimilate American culture, and threatened by Mitch's continual harassment.

13 The iconographic elaboration in which Engracia murders Mitch is latently present in previous scenes and in the psychological construction of the Latino notion of "la zona" and is key to understanding the ending. Marsha Kinder correctly states that at this point the film abandons the conventions of border films to take on those of Hispanic melodrama, where a strong and vengeful woman plans to seduce and kill her enemy:

Intending to entice and then murder Mitch, Engracia wears a seductive black dress with sequined stripes, which hypnotically holds the gaze, not only of her intended victim, but also of the spectator. When she plunges the knife into Mitch, his bright red blood splatters on her face, marking not her guilt but the extravagant flair with which she carries out the deed and signalling a shift in generic conventions from the American border film to Hispanic Melodrama. ${ }^{20}$

14 The heavily ornate style typical of melodrama, as used here in the murder scene ${ }^{21}$ not only drives home the idea of the ethical fight between the heroine who represents the morally positive in the story and her evil antagonist; it also intensifies the emotion of the moment. In fact, the way that the ethical conflict takes on a political reading is precisely through how the emotions of the spectator are guided. Melodramatic excess brings the perspective closer into a purely emotional realm for a greater identification of the spectator with the emotional motives of Engracia, which is what Borau intends with his film.

15 As in every good melodramatic film, specific objects are invested with emotion and take on important symbolic value. In this film, Engracia has a small, almost toy-like translating device that she uses to learn English. It appears in several of the more emotional scenes in the film, especially at the end, when she writes a letter to Chuck. The letter shows that she has matured into her own identity-she notably signs it with her married name: Engracia Matthews. Nevertheless, the ending of On the Line is ambiguous with regard to the process of cultural hybridization and what the final outcome of the story will be. Instead of developing the story-line of the characters, it takes us back to an abstract, metaphorical level: Mitch's dead body flows downstream, 
now impervious to human suffering, outside of time, casting a shadow of scepticism over the entire narrative of the film.

Reborn is, of course, very different from On the Line, but both films are quite similar in how they deal with the question of identity. Reborn looks at the nature of spiritualism in America at the beginning of the 80s, a phenomenon that seems to have been spliced with marketing and backed by ultraconservatives aligning themselves with "electronic preachers" in the mass media. ${ }^{22}$ Bigas Luna initially intended to combine his observations of what he considered one of the most disconcerting phenomena in America with his own reconciliation with religion:

With Reborn I'm trying to explain an era, the era of the American empire, comparing it to the Roman empire, transposing the biblical story of the Virgin Mary/Joseph/baby Jesus to the 1980s. With this story I initially criticize the commercialization of religion to get it away from all that and give it back its dignity ... Reborn is my own personal reconciliation with the religion (the church), which I highly respect, and I consider this film extremely religious. ${ }^{23}$

The film tells the story of Tom Hartley (Dennis Hopper), a successful television preacher who is famous for working miracles. The spectator knows from the beginning that they are meticulously staged, but Hartley sways the audiences with his blazing sermons, making free associations - including, for example, stating that the astronauts' journey into space is a sign of God granting his strength to men. Several business executives, led by the uncanny Reed (Kit Massengill), run the company. They discover the case of Maria, a woman in a small town in Italy, who has episodes of religious ecstasy in which the wounds of the cross appear on her hands and feet. The ambience surrounding her has an old-world feeling to it, an atmosphere of superstition, where priests, nuns, and women in black contemplate Maria in her trance. Reed is convinced that bringing in Maria will be a sure hit and he sends Mark (Michael Moriarty), Giacomo's right hand man, to get her. On their way back to the United States, Mark and Maria spend the night together in a hotel. In the rather confusing love scene that follows, a child is conceived. ${ }^{24}$ When Reed finds out, he decides to put an end to the relationship, and goes on to plan the grand spectacle of presenting Maria in an open-air televised event. On stage, Maria goes into a trance, a huge storm starts up, breaking all the electric circuits, and then a miracle actually does occur (a mute boy speaks). As Mark and Maria run out to escape, Hartley does not try to stop them, since he wants to work with someone more in tune with his bizarre ideas about astronauts rather than with an authentic Italian spiritualist. Giacomo and the other managers try to catch them but the pursuit is oddly cut short. The film ends on an undefined note as the modern Holy Family journeys down the highway with their recently-conceived child, like a modern version of the Holy Family's flight into Egypt.

As we saw in On the Line, Reborn also develops a symbolic structure through three related vectors. In one, we have the hybrid couple that drives the love story and, in this case, also represents differing religious orientations. Maria embodies the spirituality and strength of the miraculous. Her body itself, the blood of her stigmata, reveals the profound truth and mystery of her faith. Mark, on the other hand, is uncertain about religion. He is the one who sets up the false miracles for Hartley but begins to loathe his work and feel unsettled by the supernatural events he does not understand. In another vector we have the antagonists, the aseptic group of executives headed by Reed. With great capitalist spirit, they run the booming business through television and credit cards. Their main hatchet-man, Giacomo, is iconographically depicted as a caricatural 
Texan. Lastly, we have an intermediate character, the Reverend Hartley, who has no qualms about being the main actor in the extremely profitable farce, while he maintains his bizarre fusion of religion and technology. The narrative progression centers on Mark's coming to terms with Maria. He is tortured by the idea that he cannot understand who she really is or the religious reality she lives in. For Mark, Maria is a mysterious enigma that belongs to another spiritual and cultural world. Mark's shift in attitude toward Maria, from initial perplexity to full acceptance, represents Bigas Luna's own attitude toward religion and is clearly reflected in his narrative themes.

19 There is one object that takes on special symbolic meaning at several key moments in the story. It is a helicopter that appears at the beginning of the film. We do not see who is piloting it. For a moment it situates the spectator as looking down from up above. On the top of a hill, a lit-up cross stands out. Then, over the sound-track, we start to hear a sermon by Hartley. The whole effect of the sound of the motor and the helicopter blades, with the voice of Hartley preaching, the music and the illuminated cross, is much more powerful than the same speech we later hear on television. The helicopter is also present in the scene in which Mark and Maria spend the night at the hotel. At the precise moment when the child is conceived, the helicopter flashes its spotlight at the hotel windows. The symbolism here echoes the long tradition of iconographic motifs in paintings of The Annunciation, creating a special feeling of oneiric unreality, of sacred mystery. Later, as Mark and Maria flee down the highway, the helicopter flies above and appears to be guiding them.

20 The helicopter marks the end of the story of the holy family, creating a sense of atemporality that sustains the religious message of the film. But once that story-line comes to a close, there is still an element that brings us back into the present, a sceptical vision of religion as a business that has taken over American society. Hartley finally gets an astronaut to give what is actually a fairly moving speech on religion during one of his television broadcasts. In a close-up shot of the astronaut's face, the television screen he is speaking from fuses with the big screen in the movie theater, integrating the two mediums and thus leaving us with more questions than answers about American society of the 1980 s.

21 So, even though On the Line and Reborn are stylistically and thematically very different movies, they converge on particularly interesting points: narrative structure, the use of symbolism, the independent means of film production, the use of a certain type of cult figure movie star, the specifically American issues shown from the perspective of foreign auteurs. Both Borau and Bigas Luna adeptly capture the essence of America in transition, unravelling how a conservative ideology rose to hegemony in the 80s, opening up the question and offering solutions of hybridization, but not without a heavy dose of scepticism. 


\section{NOTES}

1. There are at least three similar cases of Spanish directors who went to the US in the 80s with the idea of making a film. There was Gonzalo Herralde, who made Jet Lag (Vértigo en Manhattan, 1981), Ricardo Franco, who ended up filming In and Out (1983) in Mexico, and Fernando Colomo with La línea del cielo (1984). Of these, only Colomo's film had any real impact in Spain comparable to the films we are dealing with in this article. However, we should keep in mind that Colomo's film is basically a comedy based on clichés, describing the cultural shock of a Spaniard who goes to the US to make his fortune but finds himself in a country that does not correspond to his dream. The story is told from the perspective of the Spaniard who understands neither the culture nor the language, thus differing radically from Borau and Bigas Luna's films.

2. Both directors felt uneasy with American culture and found it ultimately impossible to adapt. Bigas Luna states: "I belong to a different culture and it would have been a mistake for me to try to adapt ... Through this experience, which I am very grateful for, I have realized who I am and where I am from. ... That is what I really got out of my stay in the United States. It would be extremely hard to make a film like Jamón, jamón if you weren't Spanish and you had not lived outside Spain. It is the vision of someone who has had the opportunity to see it all from the outside. It is an ironic and technical consideration of the film." Alberto Sánchez, ed., Bigas Luna: La fiesta de las imágenes (Huesca: Festival de Cine de Huesca, 1999), 89. For his part, José Luis Borau does not hesitate to describe his stay in the United States as the worst experience in his entire career: Carlos F. Heredero, José Luis Borau: Teoría y práctica de un cineasta (Madrid: Filmoteca Española, 1990), 389.

3. Several of these aspects regarding On the Line were pointed out by Marsha Kinder in her article: "Jose Luis Borau 'On the Line' of the National/International Interface in the Post-Franco Cinema," Film Quarterly 40:2 (December 1986): 35-48.

4. Martin Amis, The Moronic Inferno and Other Visits to America (London: Penguin Books), 1987.

5. As we might expect, MacIntyre's book After Virtue (Notre Dame, Indiana: University of Notre Dame Press, 1981) and its call for a new appearance of Saint Benedict had a decisive influence on Cardinal Joseph Ratzinger, a contemporary remnant of the conservative thinking that took hold in the 80 s.

6. For antecedents to and the continuing dominance of this tradition see Earl Shorris, The Politics of Heaven: America in Fearful Times (New York: W.W. Norton, 2007).

7. Dennis Hopper had previously participated in Der Amerikanische Freund by Wim Wenders (1977) and had notably written and directed Out of the Blue in the same year as Reborn.

8. Borau was the owner of both the Spanish and the American companies that appear as producers of the film. On Bigas Luna's difficulties with production, see Sánchez, ed., Bigas Luna, 24 and following.

9. Marsha Kinder explains how On the Line was rejected by the film festivals at Berlin, Venice and Moscow as they considered it more of an American than a Spanish film. Kinder, "José Luis Borau": 36.

10. The term was coined by Virginia Higginbotham, Spanish Film under Franco (Austin, TX: University of Texas Press, 1988), 135.

11. John Hopewell, El cine español después de Franco (Madrid: Ediciones El Arquero, 1989).

12. Thomas G. Deveny, Cain on Screen: Contemporary Spanish Cinema (Metuchen and London: Scarecrow Press, 1993).

13. Marsha Kinder, Blood Cinema: The Reconstruction of National Identity in Spain (Berkeley, CA: University of California Press, 1993). 
14. Gwynne Edwards, Indecent Exposures: Buñuel, Saura, Erice \& Almodóvar (London: Marion Boyars, 1994).

15. Pascual Duarte (Ricardo Franco, 1975) is the only other film of these years that also exemplifies this rupture with the aesthetics of repression through violent naturalism.

16. The appearance in the film of Sam Jaffe, who was 93 years old at the time, is Borau's homage to John Huston's The Asphalt Jungle (1950) (cf. Kinder, "José Luis Borau": 41). The atmosphere of the film also clearly alludes to Orson Welles's 1958 border film Touch of Evil.

17. Marsha Kinder relates it to the iconographic treatment of Engracia: "The force of Engracia's screen presence is also intensified by the vibrant colors with which she is associated. Her lushly colored costumes-such as her bright turquoise robe, scarlet chemise, and royal-blue low-cut wedding dress and the vivid reds and greens of her bedroom at Boystown help convey the bright flash of Hispanic Flamboyance that she brings to virtually every scene, particularly in contrast to the drab greys, browns, and greens of many of the Texas settings. (Her first close look at the States is the seedy site where Chuck lets her out of the trunk of his car - a garbage dump under the distant tower of a Hilton Hotel.)" (Kinder, "José Luis Borau": 43).

18. Marsha Kinder also offers an interpretation, which I do not entirely agree with, on the latent homosexuality in Mitch's interest in Chuck.

19. Gloria Anzaldúa, Borderlands/La Frontera: The New Mestiza (San Francisco, Ca.: Aunt Lute Books, 1987).

20. Kinder, "José Luis Borau": 44.

21. At precisely this point, Armando Manzanero's sentimental bolero "Somos novios" can be heard. It also is played at the beginning of the film when Engracia and Chuck meet for the first time at the Papillon bar.

22. Martin Amis, "The New Evangelists," in The Moronic Inferno, 111.

23. Alberto Sánchez, ed., Bigas Luna, 107-108.

24. The most explicit part of the sequence, which is important for understanding the scene, was cut out by Bigas Luna himself, against the wishes of the producer, who put it back in as an appendix to the video edition. Bigas thought that having filmed such a sacrilegious scene had caused major problems in his own life: "Once I saw it, I felt that the biblical story was more attractive than my sceptical view of it. Many bad things started happening to me that I attributed to that. They were so bad that at the end of the day I called the producer and I told him that if he didn't cut the scene, it would be on his hands." Isabel Pisano, Bigas Luna: Sombras de Bigas, luces de Luna (Madrid: SGAE, 2001), 98.

\section{ABSTRACTS}

In the early 1980s Spanish directors José Luis Borau and Bigas Luna produced two films - On the Line and Reborn respectively - that offered a trans-national perspective on American society of the early Reaganite 1980s. On the Line focussed on the issue of trafficking Mexican immigrants; Reborn dealt with tele-evangelism. Both narratives were presented as challenges to American unity as identified in the conservative social and cultural values of the time. Each film raised the issue of social hybridity and raised the question - to which both gave ambiguous answers - of whether different cultures can co-exist within a unified, monolithic American culture. 
INDEX

Keywords: conservatism, independent film, Mexican border, national identity, Reagan Era, religion and mass media, Spanish directors in America, symbolism, transnational film

\section{AUTHORS}

VICENTE J. BENET

University Jaume I, Spain 